УДК 598.2;591.553 (571.56)

\title{
ПТИЦЫ ОЗЕРНЫХ КОТЛОВИН ЮЖНОЙ ЧАСТИ ХРЕБТА ЧЕРСКОГО
}

\author{
Кондратьев А. В., Андреев А. В. \\ ФГБУН Институт биологических проблем Севера ДВО РАН, г. Магадан \\ E-mail: akondratyev@mail.ru
}

\begin{abstract}
Приведены данные учетов фаунистического состава и численности птиц системы озерных котловин южных отрогов хр. Черского. В августе - октябре 2018 г. и в июне и августе 2021 г. обследованы котловины озер Уи, Момонтай, Малык, Дарпир, Урультун, расположенные на высотах 818-1234 м н. у. м. Всего на обследованной территории был отмечен 81 вид, среди которых в гнездовой период зарегистрировано пребывание 69 видов, при этом 56 отнесены к категории гнездящихся, а 13 - летующих. Орнитофауна обследованной системы озерных котловин характеризуется бедностью видового состава, низкой долей широко распространенных видов и относительно высокой - птиц бореально-гипоарктического и гипоарктического типа зонально-ландшафтного распространения при явном доминировании видов сибирского происхождения при сравнении с орнитофауной подгольцовых ландшафтов соседних регионов. С фауной подгольцовых ландшафтов гор Якутии орнитофауну обследованной территории сближает наличие здесь на весьма значительных высотах длиннопалого песочника, краснозобого конька и полярной овсянки, а также низкая, в противовес ландшафтам Колымского нагорья, численность щура и отсутствие соловья-красношейки, корольковой пеночки и пеночкиталовки. С подгольцовыми ландшафтами Колымского нагорья сближает наличие здесь галстучника и бурой пеночки и отсутствие варакушки. Уникальной чертой обследованных котловин является высокая численность в фауне гнездящихся видов одновременно двух форм желтых трясогузок (берингийской желтой и зеленоголовой), занимающих при этом сходные местообитания. Гнездование расширяющего свой ареал на восток дрозда-рябинника на высотах более 1000 м н. у. м. существенно дополняет представления о распространении и экологической пластичности этого вида.
\end{abstract}

Ключевые слова: авифауна, распространение птиц, хр. Черского, озерные котловины, подгольцовый пояс.

DOI: $10.34078 / 1814-0998-2021-4-23-38$

\section{ВВЕДЕНИЕ}

Авифауна гор Северо-Востока Азии до середины прошлого столетия оставалась обследованной лишь фрагментарно, несмотря на давний интерес к этому вопросу. В середине XX в. авифауну горных областей северо-восточной Якутии исследовали А. П. Васьковский (1951), К. А. Воробьев (1959), А. А. Кищинский (1968), посетившие среднегорные и высокогорные участки верховьев рр. Индигирка и Колыма. Общему анализу закономерностей состава и пространственного размещения птиц на Северо-Востоке Азии с особым вниманием к происхождению авифауны тундровой зоны, а также арктоальпийской фауны посвящена монография А. А. Кищинского (1988). Анализ закономерностей формирования авифауны гор Азиатской Субарктики приведен в монографии А. А. Романова (2013), а также в

(C) Кондратьев А. В., Андреев А. В., 2021 его специальных работах по анализу фауны и населения птиц южных отрогов Колымского нагорья (Романов и др., 2019). Вместе с тем в понимании закономерностей широтного, меридионального и высотного распределения отдельных видов птиц еще остается много вопросов вследствие труднодоступности очень многих районов горных областей Северо-Востока, для которых знания об экологических особенностях высотно-поясной дифференциации фауны и населения птиц до сих пор остаются фрагментарными. К числу таких малоисследованных районов относятся и южные части хр. Черского в области Омулевского среднегорья.

Учитывая промежуточное расположение южных отрогов цепей Черского между горами Якутии (основная часть хр. Черского, Момский хребет) и горами Колымского нагорья, вопрос о сходствах и различиях авифауны данного района 
с фауной западных и восточных горных областей представляется весьма актуальным. Кроме того, данная область обладает также рядом уникальных черт, в частности - наличием здесь крупных (более 10 км длиной) озерных котловин с глубиной озер 40 м и более, расположенных на высотах более 1000 м, относимых в горных системах Якутии и Колымского нагорья уже к подгольцовому поясу (Романов, 2013; Романов и др., 2019). Вместе с тем ни орнитофауна собственно южных отрогов хр. Черского, ни орнитофауна расположенных на высотах более 1000 м озерных котловин до сих пор были не описаны. В задачи нашего обследования входило, в первую очередь, устранение этого пробела.

\section{РАЙОН ИССЛЕДОВАНИЙ}

Исследуемый район целиком находится в бассейне р. Колыма на границе Магаданской области и Республики Саха (Якутия). Основными водными артериями являются рр. Омулевка, Урультун, Уи и Момонтай, а также озерно-речные системы, расположенные в понижении рельефа между горами Охандя, Момонтай, Омулевское среднегорье и Улахан-Чистай - Дарпирская впадина, с крупными озерами Дарпир, Момонтай, Малык и Урультун, а также обширной озерно-речной долиной в пойме рр. Уи, Момонтай и Омулевка (см. рисунок). Наиболее крупное озеро - Момонтай имеет протяженность с севера на юг 10 км и максимальную глубину более 100 м.

Общая протяженность системы озерных котловин в меридиональном направлении от южного берега оз. Малык $\left(63^{\circ} 29^{\prime}\right.$ с. ш., $147^{\circ} 52^{\prime}$ в. д. $)$ до северного берега оз. Дарпир (64ำ $11^{\prime}$ с. ш., $148^{\circ} 01^{\prime}$ в. д.) составляет 79 км, тогда как в широтном направлении она примерно вдвое меньше: рассто-

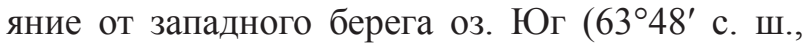
$147^{\circ} 39^{\prime}$ в. д.) до восточного берега оз. Урультун $\left(63^{\circ} 46^{\prime}\right.$ с. ш., $148^{\circ} 25^{\prime}$ в. д.) составляет 37 км.

Зеркало озер системы Уи находится на высотах 1050-1120 м н. у. м. Эта система включает такие озера, как Юг (1120 м н. у. м.), Круглое (1082 м н. У. м.), Топ и Светлое (1072 м н. у. м.), Валунное,

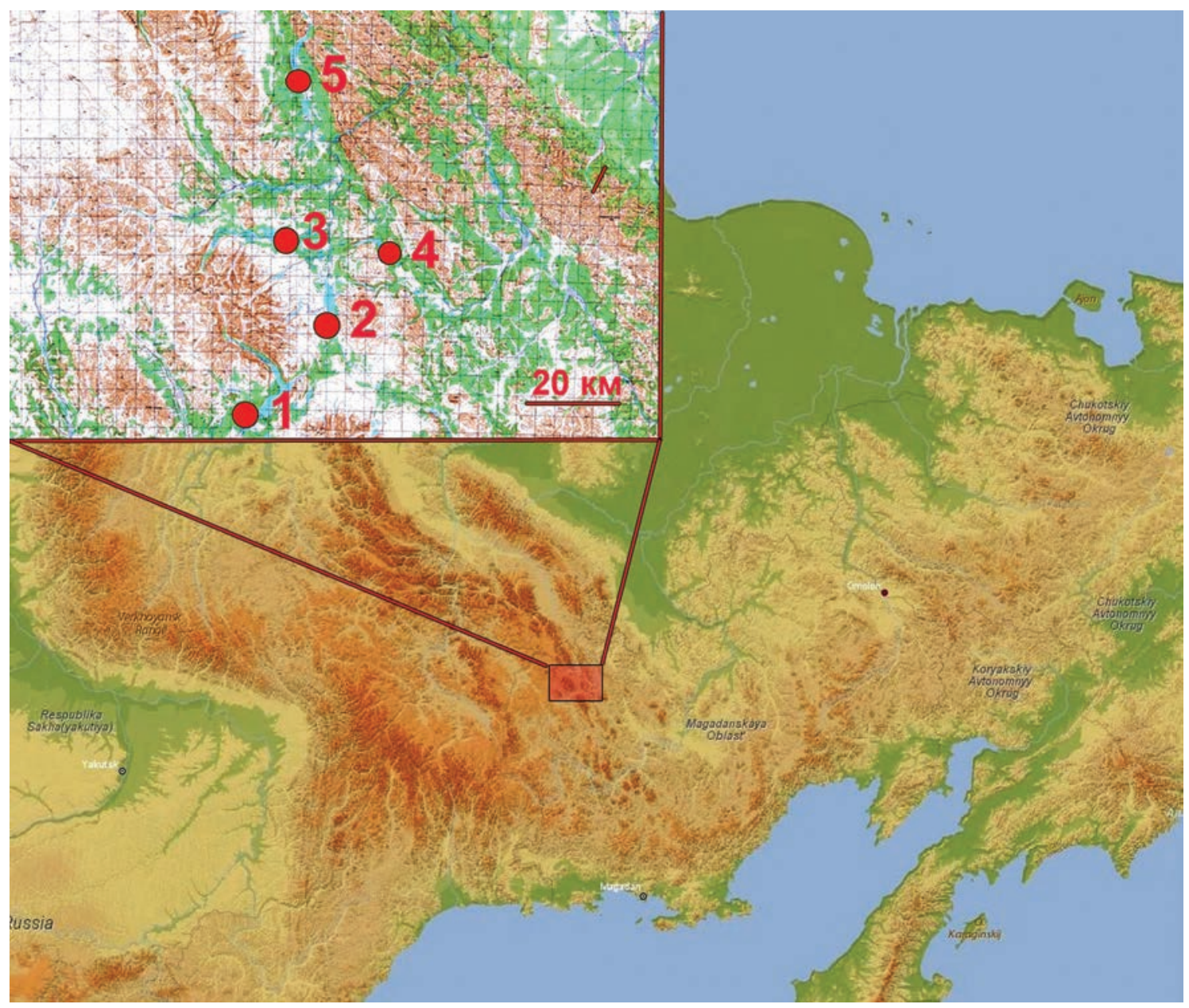

Рисунок. Расположение обследованной территории на карте северо-востока Азии. Цифрами обозначены следующие крупные озера: 1 - оз. Малык, 2 - оз. Момонтай, 3 - оз. Уи, 4 - оз. Урультун, 5 - оз. Дарпир

Figure. Location of the studied area on the map of Northeast Asia. Major lakes are numbered as follows: 1 - Lake Malyk, 2 - Lake Momontay, 3 - Lake Ui, 4 - Lake Urultun, 5 - Lake Darpir 
Уи (1056 м н. у. м.), Форель, Фигурное (1053 м н. У. м.), Утиное (1055 м н. у. м.), Каталка (1051 м н. У. м.) и другие озера в долине р. Уи, впадающей ниже в р. Момонтай. Зеркало оз. Момонтай расположено на высоте 1048 м н. у. м, Малый Дарпир - 821 м н. у. м., Дарпир - 818 м н. у. м., Малык - 951 м н. У. м. Урультун - 944 м н. у. м.

Озеро Урультун находится к востоку от р. Момонтай. С запада в него впадают два безымянных ручья, на одном из которых каскадом расположены оз. Спокойное (1049 м н. у. м.) и безымянное. С севера в оз. Урультун впадает руч. Торный, вытекающий из о3. Треугольное. К северу от о3. Треугольное (1056 м н. у. м.) находится оз. Уочат и несколько безымянных озер, впадающих протоками в р. Уочат (1084 м н. у. м., левый приток p. Урультун). Из самой южной части оз. Урультун вытекает река с одноименным названием, в 1 км от своего истока протекающая через оз. Налим. В верхнем течении в долине р. Урультун имеется большое число озер, разделенных высокими крутыми увалами, покрытыми низкорослыми беломошными лиственничниками. Высокоствольные (более 30 м высотой) лиственничники растут только на небольшой ограниченной площади укрытого от ветров глубокого ущелья западного берега оз. Урультун.

В 7 км к востоку от истока р. Момонтай в глубокой межозерной котловине расположены о3. Близнецы (1044 м н. у. м.) и Младшее (1037 м н. у. м.), из которых вытекает р. Ульбатакан, впадающая в р. Момонтай выше оз. Кемкинья (913 м н. у. м.), расположенного уже в долине p. Урультун. К западу от оз. Момонтай в предгорных узких котловинах находятся оз. Раздельное (1234 м н. у. м.) и Зеленоватое, из которых вытекает впадающий в озеро руч. Зеленый, а также оз. Балгыт (1190 м н. у. м.), из которого вытекает р. Зима, впадающая в р. Момонтай в 4 км ниже своего истока. В нижнем течении р. Зима протекает через крупное оз. Селедка (1030 м н. у. м.), окруженное придаточной системой из осоковых топей и более мелких водоемов.

В нижних частях склонов, окружающих озерную котловину, развиты зональные редкостойные лиственничники кустарничково-лишайниковые с ограниченным набором видов. На вершинах холмов и в верхних частях склонов гор они постепенно переходят в кустарничково-лишайниковые тундры, сходные с лиственничниками по видовому составу.

Система озер и проток к западу от оз. Уи характеризуется таежными ландшафтами с беломошными гривами и моховыми заболоченными понижениями. Водотоки со значительным уклоном, быстрым течением; протоки перегорожены валунами или островками с кустарничковой растительностью. К южной части оз. Уи примыка- ет участок со сложной структурой из каменистых гряд, термокарстовых водоемов сложной формы, песчаных русел временных водотоков и безлесных лишайниковых бугров.

Восточнее оз. Уи долина одноименной реки становится шире, здесь преобладают открытые ландшафты с обилием озер, заболоченных осоковых депрессий и соединяющих их каменистых и частично высохших водотоков с ивовой растительностью. Межозерные увалы покрыты как редкостойными беломошными лиственничными, так и открытыми беломошными участками с куртинами рододендрона мелкоцветкового Rhododendron parviflora. K реке примыкает множество соединенных с ней котловин, заросших осоками и арктофилой. Такие ландшафты тянутся на запад до р. Момонтай, вытекающей из северной части одноименного озера, протекающей меридионально и впадающей в р. Омулевка. С востока долина р. Момонтай ограничена пологими водораздельными холмами, покрытыми редкостойными лиственничниками.

\section{МАТЕРИАЛ И МЕТОДИКА}

В 2018 г. обследования выполнены А. В. Андреевым в период с 26.07 по 10.08 и с 24.09 по 05.10 на оз. Момонтай, Дарпир и Малый Дарпир. Им составлены аннотированные видовые списки отдельно для окрестностей о3. Момонтай и о3. Дарпир и Малый Дарпир.

В 2021 г. обследования выполнены А. В. Кондратьевым, они проводились в два этапа: с 23.06 по 28.06 были обследованы участки озерной системы Уи от о3. Юг на западе до оз. Утиное и Каталка на востоке. В этот период, помимо наблюдений автора, для некоторых редких видов использованы документированные фотографиями сведения об их встречах участником экспедиции ботаником О. А. Мочаловой. В период с 11 по 28.08 были изучены окрестности оз. Момонтай и Урультун, при этом маршрут заброски пролегал через р. Кюрбелях (950 м н. у. м.) и оз. Малык, в ходе которого также были проведены орнитологические наблюдения. При этом с 12 по 21.08 основные работы были выполнены в окрестностях о3. Урультун, а также в долине нижнего течения одноименной реки на юг до оз. Кемкинья. В этот же период в высокоствольном лиственничнике по западному берегу оз. Урультун в утреннее время проводились отловы мигрирующих лесных воробьеобразных птиц паутинными сетями. С 22 по 28.08 были обследованы районы о3. Момонтай и участки верхнего течения одноименной реки, а также оз. Близнецы и Младшее, о3. Селедка, р. Зима, оз. Балгыт, руч. Зеленый, оз. Зеленоватое и Раздельное.

В задачи исследований 2021 г., помимо составления видового списка и биологических наблю- 
дений, входило проведение учетных маршрутов по методике Равкина (1967) и оценка относительного обилия птиц. Суммарная протяженность пеших маршрутов составила 50 км в июне и 130 км в августе.

Фауна гнездящихся птиц охарактеризована по типам фаун (Штегман, 1938) и в свете представлений о зонально-ландшафтных (географогенетических) группах птиц (Чернов, 1975, 1978; Кищинский, 1988). При этом в категории фаунистических комплексов за широко распространенные приняты виды с обширным ареалом и неясным центром происхождения. В категории зонально-ландшафтных групп широко распространенными считали виды с обширным ареалом, современное распространение которых совпадает с несколькими природными зонами. В номенклатуре и при составлении списков птиц мы следовали Списку птиц Российской Федерации (Коблик, Архипов, 2014).

\section{РЕЗУЛЬТАТЫ}

Краснозобая гагара Gavia stellata (Pontopp.). Крики краснозобых гагар слышали в южной части оз. Малык 11.08.2021.

Чернозобая гагара Gavia arctica (L.). Гнездится на большинстве крупных озер системы Уи, на оз. Дарпир, Момонтай, Урультун. На крупных озерах - Круглое, Валунное, Уи, Дарпир, Момонтай - по две-три пары на каждом озере. На оз. Юг - не менее 3 пар. На меньших по размеру озерах - по одной паре. Гнездо с одним яйцом было найдено на осоковом мелководье безымянного озера, расположенного между оз. Круглое и Топ 25.06.2021. В августе пары гагар этого вида без птенцов были отмечены на оз. Дарпир, Урультун, Момонтай, Кемкинья, Селедка, Раздельное; пары с птенцами - на оз. Дарпир, Уочат, Близнецы.

Лебедь-кликун Cygnus cygnus L. Три-четыре пары кликунов отдыхали и кормились у западного берега южной части оз. Дарпир 28 и 29.09.2018. Пара птиц отмечена на группе из трех близлежащих лесных озер к востоку от оз. Уи 27.06.2021. Также пара лебедей была встречена на оз. Кемкинья 18.08.2021.

Малый лебедь Cygnus bewickii Yarr. Одиночная птица второго календарного года была отмечена над оз. Уи 23.06.2021.

Гуменник Anser fabalis (Lath.). Несколько высохших «колбасок» гусиного помета найдены на травяном бугорке на берегу оз. Дарпир при устье руч. Связной 30.08.2018. Судя по величине, помет принадлежал гуменнику. Вероятно, здесь птицы останавливались на пути весеннего пролета.

Свиязь Anas penelope L. Две самки этого вида встречены вместе с 12 чирками-свистунками на небольшом озере в долине верхнего течения p. Урультун 18.08.2021. Две самки свиязи отмечены на одном из озер верховьев р. Уочат в совместной стае с 62 чирками-свистунками 21.08.2021.

Кряква Anas platyrhynchos L. Отдельные особи, как самцы, так и самки, отмечены на протоке, соединяющей оз. Валунное и Уи, 23.06.2021. Три нелетных птенца встречены на безымянном озере в долине верхнего течения р. Урультун, 3 летных птенца - на одном из безымянных озер в пойменной части верхнего течения р. Момонтай.

Чирок-свистунок Anas crecca L. Два самца совместно с одним самцом чирка-трескунка встречена 24.06.2021 на одном из небольших озер с прибрежными зарослями осоки к востоку от оз. Уи к северу от одноименной реки. На лесных озерах к югу от реки 27.06 встречены одиночные самцы свистунка, а на одном из термокарстовых озер к югу от оз. Уи - стая из 6 летающих самцов свистунка совместно с группой из 3 самцов и 3 самок шилохвости.

В августе 2021 г. стаи хорошо летающих чирков-свистунков численностью от 6 до 70 птиц были отмечены на озерах долины верхнего течения р. Урультун (12 особей - 18.08), окрестностей о3. Уочат (62 особи, преимущественно самцы 20.08), окрестностей оз. Селедка (два выводка по 6 хорошо летающих птенцов без самок, стая из 21 особи, преимущественно самцов - 24.08), Момонтай (6 молодых - 27.08).

Клоктун Anas formosa Georg. Выводок из 5 летающих молодых встречен 21.08.2021 на о3. Треугольное. Кроме того, 12 летающих самцов клоктуна в летнем оперении были встречены на небольшом осоковом озерке в окрестностях о3. Селедка совместно с чирками-свистунками, молодыми шилохвостями и самками морской чернети 24.08.2021.

Шилохвость Anas acuta L. Группа из 3 самцов и 3 самок (совместно с группой из 6 чирковсвистунков) встречена на термокарстовом водоеме в придаточной системе к югу от оз. Уи 27.06.2021. Кроме того, в этот же день на безлесном лишайниковом увале между термокарстовыми озерами в этом районе найдено расклеванное (очевидно, чайкой) яйцо шилохвости, что свидетельствует о гнездовании этого вида в данной системе озер.

Три молодые шилохвости встречены на небольшом осоковом озерке в окрестностях о3. Селедка совместно с чирками-свистунками, клоктунами и самками морской чернети 24.08.2021.

Чирок-трескунок Anas querquedula L. Caмец встречен 24.06.2021 совместно с 2 самцами свистунка на одном из небольших озер к востоку от о3. Уи и к югу от оз. Фигурное.

Хохлатая чернеть Aythya fuligula L. Caмец этого вида встречен совместно с двумя па- 
рами морских чернетей 24.06.2021 на одном из небольших озер к востоку от оз. Уи и к югу от 03. Фигурное. Самец, державшийся совместно с парой морских чернетей, наблюдался на небольшом придаточном озере с береговым бордюром из осоки к югу от оз. Уи 27.06.2021. Перелинявший одиночный самец этого вида встречен на одном из лесных озер в нижнем течении р. Зима 24.08.2021.

Морская чернеть Aythya marila L. Две пары этого вида встречены 24.06.2021 на одном из небольших озер к востоку от оз. Уи и к югу от оз. Фигурное. Пара морских чернетей отмечена в этот же день на небольшом мелководном озерке с травянистой растительностью к северу от оз. Уи. Пара морских чернетей совместно с самцом хохлатой чернети встречена на придаточном озере с береговым бордюром из осоки к югу от оз. Уи 27.06.2021.

На одном из озер в окрестностях оз. Селедка (нижнее течение р. Зима) 24.08 встречены 3 самки морских чернетей, а на соседнем озере - группа из 4 самцов и 8 самок; 26 хорошо летающих морских чернетей (самок и молодых) отмечены на долинном озере верхнего течения р. Момонтай выше устья р. Зима 22.08.2021.

Каменушка Histrionicus histrionicus (L.). Самка с 5 птенцами возраста 25-30 дней встречена в нижнем течении р. Ульбатакан 18.08.2021.

Горбоносый турпан Melanitta deglandi (Bonap.). Несколько взрослых линяющих селезней отмечены у восточного берега оз. Малый Дарпир 07.08.2018. Присутствие этих птиц указывает на обилие мелких ракообразных в составе озерного бентоса.

Морянка Clangula hyemalis (L.). Несколько линных самок держались в северо-восточной части о3. Момонтай в первых числах августа 2018 г.

Гоголь Bucephala clangula L. Стая из 5 самцов встречена О. А. Мочаловой 26.06.2021 на одном из водораздельных озер, в 4 км к северозападу от оз. Уи.

Выводок, состоящий из самки и 5 птенцов возраста 40-45 дней, встречен на одном из озер долины верхнего течения р. Урультун 18.08.2021.

Луток Mergellus albellus (L.). Дважды встречены одиночные самки этого вида: одна птица - 18.08.2021 на озере долины р. Урультун совместно с выводком гоголей, другая - 24.08.2021 на озере в нижнем течении р. Зима совместно с группой из 4 самцов и 8 самок морских чернетей.

Длинноносый крохаль Mergus serrator $\mathbf{L}$. Пары, реже одиночные самцы и самки этого вида регулярно встречались на протоках, связывающих озера системы Уи - на протоке, соединяющей оз. Валунное и Уи, на протоке, вытекающей из оз. Светлое, а также в истоке р. Уи.
Выводок из самки и 7 птенцов возраста 25-30 дней отмечен 21.08.2021 на оз. Уочат. Другой выводок из самки и 4 птенцов возраста 35-40 дней отмечен 27.08.2021 на оз. Зеленоватое.

Белая куропатка Lagopus lagopus L. Самки с выводками из 3-5 птенцов наблюдались близ о3. Момонтай 28.07.2018 и на берегу оз. Дарпир 30.07.2018. Выводок с шестью 2-3-дневными птенцами встречен 23.06.2021 на южном берегу оз. Валунное. Самцы этого вида отмечены 23.06 к северу от о3. Валунное, а также 24.06 в истоке р. Уи.

В августе выводков белых куропаток в окрестностях оз. Урультун и Момонтай мы не видели, но регулярно встречали группы самцов этого вида числом от 7 до 13 особей в самых различных местах озерной котловины.

Тундряная куропатка Lagopus mutus Mont. Самка встречена в горных местообитаниях выше уровня леса к северу от оз. Уи 28.06.2021.

Каменный глухарь Tetrao urogalliodes Midd. Зимний помет глухаря найден О. А. Мочаловой на водораздельных с бассейном р. Омулевка лесных увалах к северу от оз. Уи.

Рябчик Tetrastes bonasia L. Зимний помет рябчика найден на водораздельных лесных увалах между р. Омулевка и оз. Юг.

Беркут Aquila chrysaetos (L.). Гнездо беркута найдено А. В. Андреевым 30.07.2018 в глубокой нише скалы на западном склоне Омулевских гор на высоте около 1200 м н. у. м. Скала располагалась при вершине небольшого и весьма крутого распадка, ниже гребня гор. Над гнездом кружилась взрослая птица, а из гнезда слышны были позывки молодой птицы. Около 14 ч взрослая птица принесла в гнездо корм.

Зимняк Buteo lagopus Pontopp. Одиночную птицу, на высоте 30 м летевшую над оз. Дарпир к югу, видел А. В. Андреев 27.09.2018.

Полевой лунь Circus cyaneus (L.). Пролетные молодые особи встречены 22.08.2021 в окрестностях оз. Момонтай, 24.08.2021 - в окрестностях оз. Селедка, 27.08.2021 - в окрестностях оз. Раздельное. Во всех случаях луни летели в западном направлении.

Ястреб-перепелятник Accipiter nisus (L.). Пролетный молодой перепелятник, летевший в западном направлении, встречен 22.08.2021 в северной части о3. Момонтай.

Ястреб-тетеревятник Accipiter gentilis (L.). Беспокоящиеся птицы отмечены 01.08.2018 на опушке леса, окаймляющего межозерный перешеек на пути к оз. Малый Дарпир и в том же месте на обратном пути. Скорее всего, это была гнездовая пара.

Пролетные одиночные молодые тетеревятники встречены 18.08.2021 в окрестностях оз. Кемкинья, 23.08.2021 - в окрестностях оз. Близнецы, 24.08.2021 - в окрестностях оз. Селедка. 
Пустельга Falco tinnunculus L. Одиночная пролетная особь встречена 21.08.2021 в окрестностях оз. Уочат.

Дербник Falco columbarius L. Одиночная пролетная особь отмечена 18.08.2021 в окрестностях оз. Кемкинья.

Сапсан Falco peregrinus Tunst. Выводок из двух беспокоящихся взрослых птиц и двух хорошо летающих молодых встречен на скалистых обрывах в западной части оз. Близнецы 23.08.2021. В период 24-28.08.2021 в окрестностях оз. Момонтай ежедневно встречались одиночные пролетные молодые сапсаны, а также группы от 2 до 4 молодых особей, летевшие в западном направлении.

Кречет Falco rusticolus L. Летящую над склонами гор птицу отметил А. В. Андреев в северной части оз. Дарпир 04.08.2018. Утром 08.08.2018 в южной части озера наблюдали сокола, делавшего ставки на озерных чаек, но, в конце концов, взявшего одну птицу прямо с воды.

Галстучник Charadrius hiaticula L. Гнездовая пара этих зуйков беспокоилась возле пуховых птенцов на берегу оз. Момонтай утром 28.07.2018, а утром 09.08.2018 в том же месте отмечены 2 взрослые и 2 летные молодые птицы, собиравшие корм вдоль берегового приплеска. Две гнездовые пары этих зуйков встречены 27.06.2021 на песчаной косе, обрамляющей южный берег котловины оз. Уи. У одной из пар было обнаружено гнездо с 4 яйцами.

Бекас Gallinago gallinago (L.). Одиночные птицы отмечены в пушицевом болоте возле оз. Момонтай 28.08.2018 и возле лесного бочага на оз. Дарпир 07.08.2018. Одиночные бекасы встречены в заболоченных ландшафтах долины р. Урультун 16 и 18.08.2021. Кроме того, 27.08.2021 в окрестностях оз. Зеленоватое в кочкарниковых местообитаниях выше границы леса отмечена высыпка, состоящая более чем из 10 особей.

Большой улит Tringa nebularia (Gunn.). Одиночные кулики держались среди затопленных кочек на южном берегу оз. Дарпир с 29.07 до 05.08.2018. Пролетные большие улиты встречались 16.08.2021 на оз. Урультун, 18.08.2021 - на озерах в долине верхней части одноименной реки, 27.08.2021 - в северной части оз. Момонтай.

Черныш Tringa ochropus L. Одиночный, явно пролетный черныш был встречен на оз. Спокойное 13.08.2021.

Фифи Tringa glareola L. Самый многочисленный кулик озерной системы Уи, также обычен на всех озерах в долинах рр. Момонтай и Урультун. Беспокоящиеся пары встречены практически на всех водоемах и сырых участках соединяющих озера водотоков. О. А. Мочаловой 23.06.2021 найдено гнездо в колее старой вездеходной доро- ги, идущей вдоль протоки, соединяющей оз. Валунное с оз. Уи.

Перевозчик Actitis hypoleucos (L.). Одиночные кулики держались среди затопленных кочек на южном берегу оз. Дарпир с 29.07 до 05.08.2018 г.

Сибирский пепельный улит Heteroscelus brevipes Vieil. Встречен 24.06.2021 в истоке p. Уи, 25.06.2021 - в истоке протоки, вытекающей из оз. Юг, а также О. А. Мочаловой 26.06.2021 на одном озере с валунными берегами на водораздельном увале между системой Уи и р. Омулевка; 20.08.2021 отмечен также на горном ручье, впадающем в оз. Урультун с запада.

Круглоносый плавунчик Phalaropus lobatus L. Стайка из 5-7 взрослых самок встречена на южном берегу оз. Дарпир 03.08.2018.

Одиночный плавунчик отмечен 24.06.2021 на заросшем осокой водоеме к югу от оз. Фигурное, 27.06.2021 группа из 9 самок плавунчиков встречена на озерке с широким осоковым бордюром совместно с морскими чернетями и свистунками. Беспокоящийся самец круглоносого плавунчика наблюдался в этот же день в заболоченных кочкарниках с глубокими старыми обводненными вездеходными колеями к югу от истока р. Уи.

Одиночный плавунчик отмечен 21.08.2021 на одном из озер в верховьях р. Уочат.

Турухтан Philomachus pugnax L. Одиночная самка этого вида отмечена 27.06.2021 на южном берегу оз. Уи, поблизости от мест беспокойства длиннопалых песочников и водоемов с морскими чернетями, свистунками и круглоносыми плавунчиками.

Длиннопалый песочник Calidris subminuta Midd. Четыре беспокоящиеся территориальные особи встречены 27.06.2021 в открытых ландшафтах, примыкающих к оз. Уи с юга. На одной из таких территорий найдено гнездо с 4 яйцами, расположенное на старой вездеходной дороге к юго-востоку от истока р. Уи.

Одиночный длиннопалый песочник встречен 24.08.2021 на травяном болоте в долине р. Момонтай.

Большой песочник Calidris tenuirostris (Horsf.). Беспокоящаяся птица встречена О. А. Мочаловой 28.06.2021 на вершине гольца к северо-западу от оз. Уи на высоте 1657 м н. у. м.

Озерная чайка Larus ridibundus $\mathbf{L}$. Несколько особей наблюдали 28.08.2018 на берегах оз. Момонтай. Возможно, на небольших озерах среди моренных холмов хр. Охандя эти птицы гнездятся. Пролетная стая из 45-50 особей озерной чайки держалась в южной части оз. Дарпир 03-08.08.2018.

Восточно-сибирская чайка Larus vegae Palmen. Самый обычный гнездящийся вид всех озер системы. Гнездятся одиночно на крупных 
гранитных глыбах, выступающих из воды в виде островков как посреди озер, так и на валунах посреди соединяющих озера проток по всей системе от оз. Юг до оз. Уи, а также на валунах, выступающих из р. Уи в обследованных верхних 3-4 км ее течения. На крупных озерах, таких как Валунное, Уи, Юг, отмечено гнездование до 3-4 пар на одном озере - обычно в разных частях водоема. На менее крупных озерах гнездится, как правило, по одной паре. В обследованных с лодки гнездах на оз. Уи были кладки из 1-3 яиц, в двух осмотренных с берега гнездах посреди других озер в кладках было по 3 яйца. В окрестностях о3. Момонтай и по течению одноименной реки 13-28.08.2021 держались более десятка пар восточно-сибирских чаек с хорошо летающими птенцами. Пары с птенцами были также отмечены на оз. Урультун, Селедка, Раздельное.

Бургомистр Larus hyperboreus Gunn. Взрослый бургомистр держался вместе с восточносибирскими чайками в южной части оз. Дарпир 30.07-8.08.2018, а также в северной части оз. Момонтай 23-28.08.2021.

Болотная сова Asio flammeus (Pontopp.). Две особи встречены на вездеходной дороге среди низкорослого лиственничника в южной части оз. Малык 12.08.2021.

Бородатая неясыть Strix nebulosa J. R. Forst. Свежее контурное перо этой крупной совы найдено на лесном перешейке между оз. Дарпир и Малый Дарпир 01.08.2018.

Белопоясный стриж Apus pacificus (Lath.) Между 30.07 и 08.08.2018, в утренние и предполуденные часы, если прекращался дождь, стайка из 6 стрижей появлялась над южным берегом Дарпира. В течение нескольких минут, иногда до получаса, птицы летали над берегом на высоте 50-70 м. В такую погоду на берегу озера в массе появлялись мелкие хирономиды, которые, по всей видимости, и привлекали сюда стрижей. Их гнездовья располагались, скорее всего, в распадках Омулевских гор.

Полевой жаворонок Alauda arvensis L. Одиночные пролетные жаворонки были встречены 11.08.2021 в открытых местообитаниях в окрестностях р. Кюрбелях.

Пятнистый конек Anthus hodgsoni Richm. Обычный вид лиственничных редколесий, встречаемый повсеместно во всей озерной системе. В июне 2021 г. в окрестностях оз. Уи наблюдалось как пение отдельных самцов, так и (чаще) беспокойство птиц с кормом у гнезд или выводков. В августе пятнистый конек был одним из самых многочисленных пролетных видов во всех лесных ландшафтах окрестностей оз. Момонтай и Урультун.

Краснозобый конек Anthus cervinus (Pall.). Около десятка особей этого вида встречены
27.06.2021 на плоских безлесных лишайниковых увалах, разделенных сложной сетью термокарстовых водоемов к югу от о3. Уи. Было отмечено пение самцов и беспокойство птиц с кормом у гнезд или выводков. В августе 2021 г. краснозобые коньки были обычны во время миграций во всех безлесных ландшафтах окрестностей о3. Момонтай.

Гольцовый конек Anthus rubescens (Tunst.). Одиночная птица встречена на луговых, с каменистыми россыпями склонах Омулевских гор 07.08.2018. Одиночная особь встречена О. А. Мочаловой 28.06.2021 на вершине гольца к северозападу от оз. Уи на высоте 1657 м н. у. м. В августе одиночный гольцовый конек был отмечен на вершине безлесной сопки в северной части о3. Урультун на высоте 1300 м н. у. м.; пролетные гольцовые коньки были обычны во всех безлесных ландшафтах окрестностей оз. Момонтай в течение всей второй половины августа.

Берингийская (желтая) трясогузка Motacilla tschutschensis J. F. Gmelin. Наряду с зеленоголовой трясогузкой является одним из самых многочисленных видов берегов рек и озер всей озерной системы. Чуть более обычна в более открытых местообитаниях к востоку от оз. Уи. В августе 2021 г. молодые берингийские трясогузки были встречены лишь в первой половине месяца в окрестностях р. Кюрбелях и оз. Малык и Момонтай 11-12.08.2021.

Зеленоголовая трясогузка Motacilla taivana (Swinch.). В июне это один из самых многочисленных видов окрестностей всех озер и проток системы Уи. 24.06.2021 встречены уверенно летающие слетки. В августе молодые желтые трясогузки обоих видов были отмечены только в окрестностях р. Кюрбелях и оз. Малык и Момонтай 11-12.08.2021.

Горная трясогузка Motacilla cinerea Tunst. В окрестностях оз. Уи в июне мы этот вид не встречали. В августе горные трясогузки, как взрослые, так и молодые, держались по берегам о3. Урультун, а также на ручье, впадающем в это озеро с запада (13-21.08.2021); взрослые птицы были отмечены на р. Ульбатакан 18.08.2021.

Белая трясогузка Motacilla alba L. Обычный обитатель берегов озер и межозерных проток. Встречается повсеместно на всех обследованных участках.

Кукша Perisoreus infaustus (L.). Обычная птица лесных урочищ всей озерной системы. Выводок из 2 взрослых и 3 молодых птиц встретили в северной части оз. Дарпир 04.08.2018 г. Пара кукш ежедневно посещала окрестности палаточного лагеря на оз. Уи в июне и окрестности лагеря на оз. Урультун в августе. Выводок из 2 взрослых и 3 молодых птиц был встречен в беломошном лиственничнике 28.06.2021. 
Кедровка Nucifraga caryocatactes (L.). Обычная птица лесных местообитаний всей озерной системы. Гнездо с 4 только что вылупившимися птенцами, расположенное в нижней части отдельно стоящей многоствольной лиственницы на высоте примерно 1.5 м, найдено 22.06.2021 в окрестностях палаточного лагеря в северозападной части оз. Уи. В первых числах августа, когда начинается созревание шишек кедрового стланика, наблюдаются заметное оживление кедровок и их транспортные перелеты над лесными гривами. В августе на оз. Урультун молодые кедровки встречались ежедневно на всех лесных участках окрестностей озера.

Ворон Corvus corax L. В июле-августе и сентябре-октябре 2018 г. пара воронов регулярно появлялась над южным берегом оз. Дарпир. В 2018 г. одиночная птица встречена 24.06.2021 в окрестностях оз. Фигурное. В августе 2021 г. одиночные вороны наблюдались в окрестностях оз. Момонтай и Близнецы. 27 августа была отмечена мигрирующая группа из 4, а 28 августа - из 7 особей.

Свиристель Bombycilla garrulus (L.). В 2021 г. стайки свиристелей от 4-6 до 8-10 особей встречали ежедневно в лесных местообитаниях всей озерной системы Уи. Такие же группы были отмечены в августе 2021 г. в окрестностях оз. Урультун и р. Момонтай.

Сибирская завирушка Prunella montanella (Pall.). В гнездовой период в июне 2021 г. не встречена. Отдельные особи отмечены во время осеннего пролета во второй половине августа 2021 г. в высокоствольном лиственничнике в западной части оз. Урультун.

Бурый дрозд Turdus eunomus Temm. Обычный гнездящийся вид лиственничных редколесий. Беспокоящиеся пары дроздов этого вида регистрировали ежедневно во всех участках обследованной озерной системы. Уверенно летающие слетки отмечены 28.06.2021 в склоновом лиственничнике на северном берегу оз. Уи. Многочисленный пролетный вид в окрестностях о3. Урультун и Момонтай в августе.

Рябинник Turdus pilaris L. В окрестностях оз. Уи в 2021 г. встречено 5 беспокоящихся пар этого вида. Три из них отмечены вдоль берегов протоки, соединяющей оз. Валунное и Уи. Расстояние между беспокоящимися парами составило примерно 500 м. У двух из них 23.06.2021 были найдены гнезда, расположенные на лиственницах на высоте примерно 3-4 м. Возраст птенцов в одном из них составлял примерно 6 сут. Еще одна пара была отмечена 24.06.2021 в истоке р. Уи. Пятая беспокоящаяся пара была встречена в этот же день в окрестностях открытого озера в 2 км к востоку от оз. Фигурное.

Группа из 5 особей встречена в окрестностях оз. Кемкинья в долине верхнего течения р. Урультун 18.08.2021.
Белобровик Turdus iliacus L. Пролетная особь отловлена в паутинную сеть 15.08.2021 в высокоствольном лиственничнике в западной части оз. Урультун.

Восточный черноголовый чекан Saxicola stejnegeri (Parrot). Характерный обитатель лесных опушек, открытых берегов озер, рек и ручьев всей озерной системы. Пение и беспокойство в июне 2021 г. отмечали ежедневно и повсеместно. В августе 2021 г. молодые чеканы были обычны по открытым участкам большинства рек и ручьев.

Синехвостка Tarsiger cyanurus (Pall.). Характерный вид таежных лиственничников, более обычен близ верхней границы леса. В июне 2021 г. пение и беспокойство отмечали в разных частях озерной системы. В августе 2021 г. - один из самых многочисленных лесных воробьиных птиц, доминировавших в отловах паутинными сетями в период пролета наряду с пеночкойзарничкой и пятнистым коньком.

Пеночка-зарничка Phylloscopus inornatus (Blyth). Характерный вид лиственничных редколесий. В июне 2021 г. пение и беспокойство этих пеночек отмечали ежедневно на всех обследованных участках озерной системы. В августе 2021 г. - один из самых многочисленных пролетных видов в лесных ландшафтах окрестностей оз. Момонтай и Урультун.

Бурая пеночка Phylloscopus fuscatus (Blyth). Характерный вид закустаренных окрестностей озер и соединяющих их водотоков. Пение и беспокойство в июне 2021 г. отмечали ежедневно в разных участках озерной системы. В августе 2021 г. пролетные бурые пеночки регулярно встречались по заросшим ивняками ручьям в окрестностях оз. Момонтай и Урультун.

Пеночка-теньковка Phylloscopus collybita (Vieil.). Пролетные теньковки встречены в высокоствольном лиственничнике в западной части оз. Урультун 18-20.08.2021.

Восточная малая мухоловка Ficedula albicilla (Pall.). Отдельные особи отмечены во время осеннего пролета во второй половине августа 2021 г. в высокоствольном лиственничнике в западной части оз. Урультун.

Пухляк Parus montanus C. V. Bald. Пары пухляков встречены в западных и восточных окрестностях оз. Урультун 18 и 20 августа 2021 г.

Сероголовая гаичка Parus cinctus Bodd. Обычный вид лиственничных редколесий. Отмечена в окрестностях оз. Дарпир в 2018 г. Пары синиц этого вида встречали ежедневно в таежных местообитаниях в окрестностях оз. Уи, Валунное, Юг в июне 2021 г., а также в окрестностях о3. Момонтай и Урультун в августе. 
Якутский поползень Sitta arctica Buturlin. Встречен в высокоствольном лиственничном лесу в западной части оз. Урультун 18-20.08.2021.

Юрок Fringilla montifringilla L. Обычный гнездящийся вид лиственничных редколесий. В июне 2021 г. встречался повсеместно и ежедневно. Также был обычен в августе во время пролета.

Чечетка Acanhtis flammea (L.). Как в июне, так и в августе 2021 г. стайки чечеток встречались повсеместно в лиственничных редколесьях озерной системы. В августе кочующие стаи числом более 50 особей были отмечены в различных ландшафтах окрестностей оз. Момонтай и Урультун.

Чечевица Carpodacus erythrinus (Pall.). Одиночный поющий самец чечевицы встречен 25.06.2021 в высоких ивовых зарослях с куртинами кедрового стланика на протоке, соединяющей оз. Топ и Валунное.

Щур Pinicola enucleator (L.). Редкий гнездящийся вид. Отмечен О. А. Мочаловой 23.06.2021 в верхней части лесного пояса к западу от оз. Уи.

Полярная овсянка Schoeniclus pallasi (Caban.). Встречена только в открытых местообитаниях к востоку от оз. Уи при обследовании этих районов 24.06 и 27.06.2021, где оказалась достаточно обычна. Отмечены как поющие самцы, так и беспокоящиеся птицы с кормом. На отдельных участках на заросших ивняками водотоках с валунным ложем, соединяющих небольшие заболоченные открытые озера, с одного места удавалось слышать и видеть до 4 пар полярных овсянок.

Овсянка-крошка Ocyris pusillus (Pall.). Наряду с зеленоголовой и берингийской трясогузками - один из самых массовых видов приозерных местообитаний всей обследованной озерноречной системы. Встречается повсеместно вдоль берегов озер и проток. Пение и беспокойство у гнезд отмечали в июне 2021 г. ежедневно. Осенью 2021 г. была обычна на пролете в окрестностях оз. Момонтай и Урультун.

Лапландский подорожник Calcarius lapponicus (L.). Пролетные небольшие стайки из $2-5$ подорожников отмечены 27.08.2021 в открытых кочкарных ландшафтах выше границы леса в окрестностях оз. Зеленоватое на высоте 1220 м H. у. м.

\section{ОБСУЖДЕНИЕ}

Разнообразие обследованных ландшафтов включает каменистые осыпи и склоны гольцового пояса, подгольцовые лишайниковые тундры с редкими куртинами кедрового стланика, лиственничные редколесья лесного пояса, болотные комплексы, озера и соединяющие их протоки, разъединенные высокими беломошными гри- вами, частично открытыми, но местами поросшими низкорослым лиственничником, а также открытые заболоченные пространства по бортам широких речных долин.

У большинства гнездящихся видов в последней декаде июня были отмечены кладки с яйцами либо с недавно вылупившимися птенцами. Покинувшие гнездо слетки были отмечены у кукши, зеленоголовой и берингийской трясогузок, бурого дрозда. Водоплавающие птицы еще не приступили к линьке маховых перьев, и все хорошо летали.

Фауна птиц гольцового пояса представлена только двумя видами - большим песочником и гольцовым коньком. В подгольцовом поясе отмечены тундряная куропатка, а также виды, проникающие сюда из лесной зоны, - кедровка, синехвостка, овсянка-крошка.

В подгольцовом поясе фоновыми видами являются белая куропатка, а из воробьеобразных обычными видами были юрок, пятнистый конек, кукша, сероголовая гаичка, чечетка, свиристель, бурый дрозд, пеночка-зарничка, овсянкакрошка.

Более богаты видами водно-болотные комплексы. Наиболее обычные виды - фифи, восточно-сибирская чайка, чернозобая гагара, из воробьеобразных - белая, берингийская и зеленоголовая трясогузки, восточный черноголовый чекан, овсянка-крошка. На водотоках с быстрым течением обитают длинноносый крохаль и сибирский пепельный улит. На заросших по берегам водной растительностью небольших по площади водоемах - кряква, шилохвость, чироксвистунок, морская и хохлатая чернети, круглоносый плавунчик.

Ограничены специфическими местообитаниями встречи таких локально распределенных видов, как галстучник, длиннопалый песочник, турухтан, краснозобый конек, рябинник, полярная овсянка.

Список птиц, отмеченных в июне 2021 г., включает 47 зарегистрированных видов. В августе 2021 г. список зарегистрированных видов был значительно расширен - как в связи с обследованием более широкого спектра местообитаний, так и по причине того, что видовой состав был обогащен пролетными видами водоплавающих птиц, дневных хищников, куликов и воробьеобразных. Следовательно, список птиц в августе насчитывал уже 61 вид. Общий список птиц, зарегистрированных в 2021 г., насчитывает, таким образом, 70 видов.

В целом, вместе с видами, отмеченными при обследовании оз. Дарпир и Момонтай в 2018 г., но не найденными в 2021 г., на обследованной территории был обнаружен 81 вид, среди которых 12 были встречены только в период осенних ми- 
граций. В летний же период зарегистрировано пребывание 69 видов, среди которых 56 отнесены к категории гнездящихся, а 13 - летующих. Лишь 6 из них (рябчик, каменный глухарь, бородатая неясыть, восточная малая мухоловка, пухляк и якутский поползень) оказались ограничены в своем распространении местообитаниями горно-таежного пояса, где встречались преимущественно в высокоствольных долинных лиственничниках. Горно-тундровые местообитания собственно гольцового пояса были обследованы достаточно фрагментарно, и здесь были встречены только большой песочник и гольцовый конек, а также зарегистрированы следы пребывания тундряной куропатки. Ни хрустана (Charadrius morinellus), ни рогатого жаворонка (Eremophila alpestris), ни каменки (Oenanthe oenanthe), ни горного вьюрка (Leucosticte arctoa), которых К. А. Воробьев (1959) встречал в более северных и западных районах хр. Черского, мы не отметили. Не отметили мы также сибирской чечевицы (Carpodacus roseus) и альпийской завирушки (Prunella collaris), населяющих гольцовый пояс Колымского нагорья (Кищинский, 1968; Романов и др., 2019). Возможно, это объясняется как относительной редкостью данных видов, так и недостаточной исследованностью нами собственно гольцовых биотопов.

В целом же общее число видов, которые могут отнесены к категории гнездящихся, вполне соответствует числу видов данной категории, выявленных в 2016 г. А. А. Романовым с соавторами для локальных фаун южных отрогов Колымского нагорья - ими в 11 различных пунктах зарегистрированы 74 вида с подтвержденным, возможным или вероятным гнездованием, что составляет $65 \%$ от общей гнездовой авифауны региона. В каждой из локальных фаун авторы отмечали наличие от 23 до 44 видов (Романов и др., 2019).

Сравнение фаунистического состава обследованных озерных котловин восточной части хр. Черского с фауной его западных и северных областей (Воробьев, 1959, 1963; Романов, 2013) и лежащих к востоку областей Колымского нагорья (Кищинский, 1968, 1988; Романов и др., 2019) выявляет как закономерности, так и особенности фауны этого региона. С учетом того, что обследованная территория расположена, вопервых, достаточно высоко над уровнем моря (уровень зеркала обследованных в гнездовой период водоемов варьировал от 913 до 1234 м н. у. м.) и, во-вторых, лишена развитых речных пойм, орнитофауна оказалась в значительной степени обеднена. Так, в ближайших окрестностях обследованной озерной котловины (в долинах p. Берелех, Буркандья, Омулевка), расположенных лишь немного ниже - на высотах 820-860 м н. у. м., - в июне 2021 г. были вполне обычны такие виды, как сизая чайка (Larus canus), речная крачка (Sterna hirundo), обыкновенная кукушка (Cuculus canorus), корольковая пеночка (Phylloscopus proregulus), таловка (Phylloscopus borealis), певчий сверчок (Locustella certhiola), соловей-красношейка (Luscinia calliope). В обследованных озерных котловинах мы эти виды не отмечали нигде.

Основу местообитаний обследованных озерных котловин составляют лиственничные редколесья разной степени разреженности, а также ивняковые и ерниковые заросли вдоль водотоков - типичные биотопы горно-редколесных ландшафтов подгольцового пояса. Именно с этими ландшафтами оказались связаны 47 видов из списка гнездящихся. Таксономическая структура гнездовой орнитофауны обследованной озерной котловины соответствует зональным и ландшафтным особенностям Северо-Востока Азии в целом и включает в себя 8 отрядов с доминированием трех из них - воробьеобразных, ржанкообразных и гусеобразных, на долю которых приходится $80.4 \%$ всех гнездящихся видов (табл. 1).

С точки зрения представленности в фауне обследованных озерных котловин птиц различных зонально-ландшафтных групп наиболее многочисленными были виды бореального, гипоарктического и бореально-гипоарктического распространения, такие как чернозобая гагара, морская чернеть, фифи, восточно-сибирская чайка, берингийская и зеленоголовая трясогузки, пятнистый конек, зарничка, бурый дрозд, чечетка, юрок, овсянка-крошка, а также широко распространенные виды - чирок-свистунок, белая трясогузка, черноголовый чекан. Обычными, хотя и не столь многочисленными были такие бореальные виды, как свиристель, синехвостка, сероголовая гаичка, кедровка, кукша. Немногочисленными, но характерными видами озерной котловины оказались следующие гипоаркты: галстучник, турухтан, круглоносый плавунчик, длиннопалый песочник, краснозобый конек, бурая пеночка и полярная овсянка. Обычными видами рек и озер подгольцового пояса были каменушка, длинноносый крохаль, местами - гоголь и сибирский пепельный улит, белая и горная трясогузки.

Такой видовой состав является достаточно характерным для орнитофауны подгольцового пояса гор Азиатской Субарктики (Романов, 2013). Тем не менее ряд выявленных особенностей состава орнитофауны обследованной озерной котловины оказался в достаточной степени своеобразным. Прежде всего, необходимо отметить его переходный характер между фаунами более западных горных районов Якутии и более восточных районов Колымского нагорья. С орнитофауной горных районов Якутии фауну озерных 
Таблица 1. Таксономический состав гнездовой орнитофауны озерных котловин южной части хр. Черского в сравнении с общей гнездовой орнитофауной гор Якутии и Колымского нагорья

Table 1. Taxonomic structure of the nesting avifauna in lake depressions of the Chersky Ridge southern part compared with the general structure of the nesting avifauna in Yakutia's mountains and the Kolyma Highland

\begin{tabular}{|c|c|c|c|c|c|c|c|c|}
\hline \multirow{3}{*}{ Отряд } & \multicolumn{8}{|c|}{ Число видов } \\
\hline & \multicolumn{4}{|c|}{ Озерные котловины } & \multicolumn{2}{|c|}{ Горы Якутии* } & \multicolumn{2}{|c|}{$\begin{array}{c}\begin{array}{c}\text { Колымское } \\
\text { нагорье* }\end{array} \\
\end{array}$} \\
\hline & $\begin{array}{c}\text { всего } \\
\text { летующих }\end{array}$ & $\%$ & гнездящихся & $\%$ & всего & $\%$ & всего & $\%$ \\
\hline Гагарообразные & 2 & 2.9 & 1 & 1.8 & 2 & 1.5 & 3 & 2.2 \\
\hline Поганкообразные & 0 & 0.0 & 0 & 0.0 & 1 & 0.7 & 1 & 0.7 \\
\hline Гусеобразные & 16 & 23.2 & 8 & 14.3 & 17 & 13.1 & 20 & 15.0 \\
\hline Соколообразные & 5 & 7.2 & 4 & 7.1 & 12 & 9.2 & 13 & 9.8 \\
\hline Курообразные & 4 & 5.8 & 4 & 7.1 & 4 & 3.1 & 4 & 3.0 \\
\hline Ржанкообразные & 13 & 18.8 & 10 & 17.9 & 28 & 21.5 & 22 & 16.5 \\
\hline Совообразные & 1 & 1.5 & 1 & 1.8 & 5 & 3.8 & 5 & 3.7 \\
\hline Кукушкообразные & 0 & 0.0 & 0 & 0.0 & 2 & 1.5 & 2 & 1.5 \\
\hline Стрижеобразные & 1 & 1.5 & 1 & 1.8 & 1 & 0.7 & 1 & 0.7 \\
\hline Дятлообразные & 0 & 0.0 & 0 & 0.0 & 3 & 2,3 & 3 & 2.2 \\
\hline Воробьеобразные & 27 & 39.1 & 27 & 48.2 & 55 & 42.6 & 59 & 44.7 \\
\hline Всего & 69 & 100 & 56 & 100 & 130 & 100 & 133 & 100 \\
\hline
\end{tabular}

*По данным А. А. Романова (2013).

котловин южных частей хр. Черского сближает присутствие здесь таких видов, как длиннопалый песочник, краснозобый конек, полярная овсянка, наличие в подгольцовом поясе синехвостки. Однако при этом здесь не была отмечена варакушка (Luscinia svecica), характерная для северных и западных районов хр. Черского (Воробьев, 1959, 1963; Романов, 2013), но отсутствующая или исключительно редкая в Колымском нагорье (Кищинский, 1968). С орнитофауной Колымского нагорья фауну обследованных высокогорных озерных котловин сближает присутствие здесь галстучника, бурой пеночки, но отличает наличие на столь значительных высотах краснозобого конька и полярной овсянки (в Колымском нагорье краснозобый конек в горах не отмечен, а полярная овсянка не поднимается выше 600 м н. у. м. (Романов, 2013)), а также отличает отсутствие здесь достаточно характерных для подгольцового пояса Колымского нагорья соловья-красношейки, корольковой пеночки и таловки и низкая численность обыкновенной чечевицы и щура. Первые два вида в горах Якутии не поднимаются выше 800 м н. у. м., тогда как в Колымском нагорье они отмечены на высотах 1100-1500 м н. у. м. (Кищинский, 1968; Романов, 2013; Романов и др., 2019). В Колымском нагорье корольковая пеночка, чечевица и щур относятся к доминантам и субдоминантам подгольцового пояса и даже проникают в гольцовый пояс (Романов и др., 2019), тогда как на обсле- дованной нами территории чечевица и щур были встречены единично (табл. 2), а корольковую пеночку мы не встречали вовсе, хотя на сопредельных территориях на высотах ниже 850 м она уже была обычна. В центральной части хр. Черского корольковая пеночка отсутствует (Воробьев, 1963; Романов, 2013).

Сближает с фауной гор Якутии и наличие в лесном поясе якутского поползня, тогда как все Колымское нагорье, вплоть до его северных границ, населяет обыкновенный поползень (Кищинский, 1968), а южная граница распространения якутского поползня требует уточнения.

Отдельного внимания заслуживает обилие в Дарпирской котловине как берингийской, так и зеленоголовой трясогузки. Оба вида оказались многочисленными на гнездовании (см. табл. 2) и при этом занимали сходные местообитания. Сходными оказались у них и сроки размножения. В монографии А. А. Кищинского «Орнитофауна северо-востока Азии» на карте распространения подвидов желтой трясогузки в восточной части хр. Черского стоят знаки вопроса (Кищинский, 1988). К. А. Воробьев упоминает, что форма pleха (рассматриваемая в настоящее время в качестве подвида берингийской трясогузки) спускается к югу лишь до широты полярного круга, тогда как для хр. Черского характерна желтая трясогузка формы taivana (Воробьев, 1963). А. А. Кищинский для всего Колымского нагорья указывает только форму taivana, при этом упоминает, что 
Таблица 2. Обилие регулярно встречающихся гнездящихся видов птиц озерных котловин южных отрогов хр. Черского по данным учетов 2021 г.

Table 2. Abundance of the most common nesting bird species in lake depressions of the Chersky Ridge southern part by the data of bird counts in 2021

\begin{tabular}{|c|c|c|}
\hline Вид & $\begin{array}{c}\text { Обилие, } \\
\text { особей/км² }\end{array}$ & $\begin{array}{c}\text { Доля } \\
\text { участия, \% }\end{array}$ \\
\hline Чернозобая гагара & 0.5 & 0.3 \\
\hline Шилохвость & 0.4 & 0.2 \\
\hline Кряква & 0.05 & 0.03 \\
\hline Чирок-свистунок & 0.7 & 0.4 \\
\hline Клоктун & 0.1 & 0.1 \\
\hline Морская чернеть & 0.3 & 0.1 \\
\hline Гоголь & 0.1 & 0.1 \\
\hline Длинноносый крохаль & 0.3 & 0.2 \\
\hline Белая куропатка & 0.2 & 0.1 \\
\hline Галстучник & 0.1 & 0.05 \\
\hline Фифи & 0.3 & 0.2 \\
\hline Восточно-сибирская чайка & 0.8 & 0.4 \\
\hline Пятнистый конек & 8.1 & 4.3 \\
\hline Краснозобый конек & 0.1 & 0.1 \\
\hline Гольцовый конек & 0.08 & 0.1 \\
\hline Зеленоголовая трясогузка & 24 & 12.8 \\
\hline Берингийская трясогузка & 18 & 9.6 \\
\hline Горная трясогузка & 0.01 & 0.01 \\
\hline Белая трясогузка & 8 & 4.3 \\
\hline Кукша & 4 & 2.1 \\
\hline Кедровка & 14.5 & 7.7 \\
\hline Ворон & 0.02 & 0.01 \\
\hline Свиристель & 4 & 2.1 \\
\hline Бурая пеночка & 2.5 & 1.3 \\
\hline Пеночка-зарничка & 15 & 8.0 \\
\hline $\begin{array}{l}\text { Восточный черноголовый } \\
\text { чекан }\end{array}$ & 8 & 4.3 \\
\hline Синехвостка & 4 & 2.1 \\
\hline Бурый дрозд & 14 & 7.5 \\
\hline Рябинник & 0.3 & 0.1 \\
\hline Пухляк & 0.05 & 0.03 \\
\hline Сероголовая гаичка & 9 & 4.8 \\
\hline Якутский поползень & 0.01 & 0.01 \\
\hline Юрок & 8 & 4.3 \\
\hline Чечетка & 14 & 7.5 \\
\hline Чечевица & 0.05 & 0.03 \\
\hline Щур & 0.05 & 0.03 \\
\hline Полярная овсянка & 0.02 & 0.01 \\
\hline Овсянка-крошка & 26 & 13.9 \\
\hline
\end{tabular}

ее основные гнездовые местообитания - приморская равнинная тундра (Кищинский, 1968). А. А. Романов в своем анализе авифауны гор Азиатской Субарктики все формы желтых трясогузок рассматривает вместе, указывая при этом, вслед за А. А. Кищинским, на их отсутствие в подгольцовом поясе гор Колымского нагорья (Романов, 2013). Таким образом, обнаруженное нами гнездование обоих видов в открытых местообитаниях высокогорных озерных котловин, во-первых, существенно расширяет представления о южной границе распространения берингийской трясогузки, проходящей на $3^{\circ}$ южнее, чем это указано К. А. Воробьевым (1963) и А. А. Кищинским (1988), а во-вторых, свидетельствует о наличии у этих двух форм зоны симпатрии, ранее не получившей освещения в литературе.

Особенностью современного этапа динамики орнитофауны Северо-Востока Азии в целом является последовательное продвижение в последнее десятилетие на восток вида европейской фауны - дрозда-рябинника (Кондратьев, 2014; Лобков, 2015; Дорогой, 2018; Слепцов, 2018; Синельникова, 2018). Нередким оказался рябинник на гнездовании и в озерной котловине системы р. Уи. Беспокояшиеся пары с кормом и гнезда этого вида с птенцами мы находили вдоль р. Уи как выше, так и ниже одноименного озера на высотах 1050-1060 м н. у. м. До сих пор большинство гнездовых находок рябинника на Северо-Востоке Азии были приурочены к долинным ландшафтам и связаны, преимущественно, с открытыми местообитаниями антропогенного генезиса вблизи населенных пунктов (Лобков, 2015; Синельникова, 2018; Слепцов, 2018). Находка гнездового поселения рябинников в природных открытых местообитаниях подгольцового пояса озерной котловины Уи на высотах более 1000 м н. у. м. существенно расширяет представления о характере распространения и экологическом потенциале данного вида на этапе наблюдаемого расширения ареала.

При сравнении фауны озерных котловин Омулевского среднегорья с фауной горно-таежных ландшафтов региона в целом обращает на себя внимание исключительно высокая доля здесь видов сибирского типа фауны и существенная - видов арктического типа. Доля широко распространенных видов и видов китайского типа фауны существенно меньше доли соответствующих видов в подгольцовом поясе Колымского нагорья (табл. 3).

При анализе соотношения зонально-ландшафтных групп в фауне обследованных озерных котловин обращает на себя внимание высокая доля прежде всего бореально-гипоарктических и бореальных видов и очень низкая - широко распространенных видов, тогда как доля гипоарктов, гемиарктов, а также альпийских и арктоальпий- 
Таблища 3. Соотношение фаунистических комплексов в составе гнездовой орнитофауны озерных котловин южной части хр. Черского в сравнении с общей гнездовой орнитофауной гор Якутии и Колымского нагорья

Table 3. Faunistic complexes in the structure of nesting avifauna in lake depressions in the Chersky Ridge southern part compared with the general structure of the nesting avifauna in Yakutia's mountains and the Kolyma Highland

\begin{tabular}{|c|c|c|c|c|c|c|c|c|}
\hline \multirow{3}{*}{ Фаунистический комплекс } & \multicolumn{8}{|c|}{ Число видов } \\
\hline & \multicolumn{4}{|c|}{ Озерные котловины } & \multicolumn{2}{|c|}{ Горы Якутии* } & \multicolumn{2}{|c|}{$\begin{array}{c}\text { Колымское } \\
\text { нагорье* }\end{array}$} \\
\hline & $\begin{array}{c}\text { всего } \\
\text { летующих }\end{array}$ & $\%$ & $\begin{array}{c}\text { гнездя- } \\
\text { щихся }\end{array}$ & $\%$ & всего & $\%$ & всего & $\%$ \\
\hline Арктические & 12 & 17.4 & 7 & 12.5 & 22 & 16.9 & 15 & 11.3 \\
\hline Сибирские & 41 & 59.4 & 36 & 64.3 & 55 & 42.3 & 56 & 42.1 \\
\hline Европейские & 1 & 1.5 & 0 & 0.0 & 1 & 0.8 & 1 & 0.7 \\
\hline Тибетские & 1 & 1.5 & 1 & 1.8 & 3 & 2.3 & 4 & 3.0 \\
\hline Китайские & 3 & 4.3 & 3 & 5.4 & 5 & 3.9 & 11 & 8.3 \\
\hline Широко распространенные & 11 & 15.9 & 9 & 16.0 & 44 & 33.8 & 46 & 34.6 \\
\hline Всего & 69 & 100 & 56 & 100 & 130 & 100 & 133 & 100 \\
\hline
\end{tabular}

*По данным А. А. Романова (2013).

ских видов сравнима с долей этих видов с их долей на территории в целом (табл. 4).

Это свидетельствует о том, что обеднение фаунистического состава происходит, главным образом, за счет широко распространенных видов, доля которых закономерно снижается с высотой при переходе от горно-таежного пояса к подгольцовому (Романов и др., 2019). При этом в обследованных озерных системах отмечена значительно более высокая доля гипоарктических (12\%) и бореально-гипоарктических видов (32\%) при сходной доле бореальных (37\%) и очень низкой доле широко распространенных (12\%) видов в подгольцовом поясе по сравнению с локальными фаунами подгольцового пояса Колымского нагорья, где доля гипоарктических видов составляет всего $3 \%$, бореально-гипоарктических - $24 \%$, бореальных - 30 \%, а широко распространенных 37 \% (Романов и др., 2019). Это может объясняться более высокой представленностью гусеобразных и ржанкообразных птиц гипоарктического и бореально-гипоарктического типа распространения в фауне обследованных озерных котловин. На территории Колымского нагорья таких высокогорных озерных систем мало, и специальных исследований орнитофауны там проведено не было.

Таблица 4. Соотношение зонально-ландшафтных групп в составе гнездовой орнитофауны озерных котловин южной части хр. Черского в сравнении с общей гнездовой орнитофауной гор Якутии и Колымского нагорья

Table 4. Zonal-landscape groups of birds in the structure of the nesting avifauna in lake depressions of the Chersky Ridge southern part compared with the general structure of the nesting avifauna in Yakutia's mountains and the Kolyma Highland

\begin{tabular}{|c|c|c|c|c|c|c|c|c|}
\hline \multirow{3}{*}{$\begin{array}{c}\text { Зонально- } \\
\text { ландшафтная } \\
\text { группа }\end{array}$} & \multicolumn{8}{|c|}{ Число видов } \\
\hline & \multicolumn{4}{|c|}{ Озерные котловины } & \multicolumn{2}{|c|}{ Горы Якутии* } & \multicolumn{2}{|c|}{$\begin{array}{c}\text { Колымское } \\
\text { нагорье* }\end{array}$} \\
\hline & $\begin{array}{c}\text { всего } \\
\text { летующих }\end{array}$ & $\%$ & $\begin{array}{c}\text { гнездя- } \\
\text { щихся }\end{array}$ & $\%$ & всего & $\%$ & всего & $\%$ \\
\hline Альпийские & 2 & 2.9 & 2 & 3.6 & 5 & 3.8 & 6 & 4.5 \\
\hline Арктоальпийские & 1 & 1.5 & 1 & 1.8 & 5 & 3.8 & 3 & 2.2 \\
\hline Гемиарктические & 4 & 5.8 & 0 & 0.0 & 11 & 8.5 & 7 & 5.3 \\
\hline Гипоарктические & 9 & 13.0 & 7 & 12.5 & 16 & 12.3 & 14 & 10.5 \\
\hline Бореально-гипоарктические & 19 & 27.6 & 18 & 32.1 & 23 & 17.7 & 22 & 16.5 \\
\hline Бореальные & 25 & 36.2 & 21 & 37.5 & 31 & 23.8 & 39 & 29.3 \\
\hline Широко распространенные & 9 & 13.0 & 7 & 12.5 & 39 & 30.1 & 42 & 31.7 \\
\hline Всего & 69 & 100 & 56 & 100 & 130 & 100 & 133 & 100 \\
\hline
\end{tabular}

*По данным А. А. Романова (2013). 
В целом же в Магаданской области озерные системы приурочены, в основном, к речным долинам или равнинам морского побережья и расположены на небольших высотах.

Как показано для локальных фаун Колымского нагорья, именно для подгольцового пояса характерны минимальные показатели сходства локальных авифаун в противовес более высокой общности фаун горно-таежного и гольцового поясов (Романов и др., 2019), в свете чего выявленное своеобразие фаунистического состава озерных котловин южных отрогов хр. Черского представляется закономерным.

С орнитофауной равнинных озерных комплексов, например, ландшафтов Кавинской лесотундры (Кречмар, 2014), орнитофауну обследованной высокогорной котловины сближает высокая доля бореально-гипоарктических и гипоарктических видов, но отличает отсутствие здесь обычных на побережье бореальных и широко распространенных видов водоплавающих и околоводных птиц «пойменного» комплекса - поганок, аистообразных, южных видов уток, крачек, многих видов куликов, чаек, а также полное отсутствие таких лесных видов, как кукушки и дятлы. От орнитофауны равнинных озерных комплексов более северных ландшафтов лесной зоны Колымской низменности (Кречмар и др., 1978) орнитофауну озерных котловин хр. Черского отличает низкая доля не только широко распространенных, но и гемиарктических видов, таких как бурокрылая ржанка (Pluvialis fulva), средний кроншнеп (Numenius phaeopus), длиннохвостый поморник (Stercorarius longicaudus).

\section{ЗАКЛЮЧЕНИЕ}

Орнитофауна обследованной системы озерных котловин южной части хр. Черского характеризуется бедностью видового состава, низкой долей широко распространенных видов и относительно высокой долей птиц бореальногипоарктического и гипоарктического типа зонально-ландшафтного распространения при явном доминировании видов сибирского происхождения при сравнении с орнитофауной подгольцовых ландшафтов соседних регионов. Это обусловлено высокой долей озер, рек, ручьев и других обводненных местообитаний, способствующих проникновению сюда гипоарктических видов, не привязанных к лесной растительности. C подгольцовыми ландшафтами Якутии орнитофауну обследованной территории сближает наличие здесь на столь значительных высотах длиннопалого песочника, краснозобого конька и полярной овсянки, низкая (в противовес ландшафтам Колымского нагорья) численность щура, но отличает отсутствие (как и в ландшафтах Колымского нагорья) варакушки. С подголь- цовыми ландшафтами Колымского нагорья сближает наличие здесь галстучника и бурой пеночки, но отличает отсутствие на этих высотах соловьякрасношейки, корольковой пеночки и пеночкиталовки - видов, отсутствующих также в подгольцовых ландшафтах Якутии. Уникальными чертами обследованной котловины является высокая численность в фауне гнездящихся видов одновременно двух форм желтых трясогузок (берингийской желтой и зеленоголовой), занимающих при этом сходные местообитания. Гнездование расширяющего свой ареал дрозда-рябинника на высотах более 1000 м н. у. м. также является уникальным и не описанным ранее.

\section{БЛАГОДАРНОСТИ}

Проведение орнитологического обследования труднодоступных озерных котловин в южных отрогах хр. Черского оказалось возможным благодаря грантам РГО «Озерно-речные системы высокогорных ледниковых равнин криолитозоны - 07/2018-Р» и «Экспедиция к южным отрогам хребта Черского, юг Омулевского среднегорья - 15/2021-Р». Сведения о встречах некоторых видов птиц любезно предоставлены участником экспедиции 2021 г. ботаником О. А. Мочаловой.

\section{ЛИТЕРАТУРА}

Васьковский А. П. Заметки о находках некоторых видов птиц в верховьях рек Колымы и Индигирки // Бюллютень МОИП. Отделение биол. 1951. Т. 56. Вып. 1. C. $22-25$.

Воробьев К. А. Орнитологические исследования в хребте Черского // Орнитология. 1959. Вып. 2. С. 115 121.

Воробьев К. А. Птицы Якутии. Москва : Изд-во АН CCCP, 1963. $336 \mathrm{c}$.

Дорогой И. В. Второй случай гнездования рябинника Turdus pilaris в северном Охотоморье // Русский орнитологический журнал. 2018. Т. 27, № 1648. С. 3691-3693.

Кищинский А. А. Птицы Колымского нагорья. Москва : Наука, 1968. 184 с.

Кищинский A. A. Орнитофауна северо-востока Азии: История и современное состояние. Москва : Наука, 1988. 288 с.

Коблик Е. А., Архипов В. Ю. Фауна птиц стран северной Евразии в границах бывшего СССР. Списки видов // Зоологические исследования № 14. Москва : Товарищество научных изданий КМК, 2014. 172 с.

Кондратьев А. В. Первый случай гнездования рябинника Turdus pilaris в Магаданской области // Русский орнитологический журнал. 2014. Т. 23, № 1045. C. 2785-2787.

Кречмар A. В. Экология и мониторинг птиц приохотской равнинной лесотундры на примере ландшафтов бассейна реки Кава. Владивосток : Дальнаука, 2014. 288 с.

Кречмар А. В., Андреев А. В., Кондратьев А. Я. Экология и распространение птиц на Северо-Востоке СССР. Москва : Наука, 1978. 194 с. 
Лобков E. $Г$. Статус дрозда-рябинника Turdus pilaris на русском Дальнем Востоке: прогрессирующее расширение ареала // Русский орнитологический журнал. 2015. Т. 24, № 1114. С. 789-791.

Равкин Ю. С. К методике учета птиц лесных ландшафтов // Природа очагов клещевого энцефалита на Алтае / отв. ред. А. А. Максимов. Новосибирск : Наука, 1967. С. 66-75.

Романов А. А. Авифауна гор Азиатской Субарктики: закономерности формирования и динамики. Москва : Русское общество сохранения и изучения птиц имени М. А. Мензбира.2013. 358 с.

Романов А. А., Мелихова Е. В., Миклин Н. А., Яковлев $B$. $O$. Анализ фауны и населения птиц южных отрогов Колымского нагорья // Зоологический журнал. 2019. T. 98, № 8. C. 915-927.
Синельникова Н. В. Рябинник Turdus pilaris - новый гнездящийся вид на северо-западе Магаданской области // Русский орнитологический журнал. 2018. Т. 27, № 1594. С. 1705-1707.

Слепиов Ю. А. Гнездование рябинника Turdus pilaris в верхнем течении Колымы // Русский орнитологический журнал. 2018. Т. 27, № 1700. С. 58005802.

Чернов Ю. И. Природная зональность и животный мир суши. Москва : Мысль, 1975. 222 с.

Чернов Ю. И. Структура животного населения Субарктики. Москва : Наука, 1978. 167 с.

Штегман Б. К. Основы орнитогеографического деления Палеарктики // Фауна СССР. Птицы. Т. 1. Вып. 2 / отв. ред. С. А. Зернов. Москва ; Ленинград : Изд-во АН СССР, 1938. 164 с.

\title{
BIRDS OF THE LAKE BASINS IN THE SOUTHERN PART OF CHERSKY MOUNTAIN RIDGE
}

\author{
A. V. Kondratyev, A. V. Andreev \\ Institute of Biological Problems of the North, Magadan
}

\begin{abstract}
New data and analysis of the avifauna and bird species abundance are given for the lake systems of the southern part of the Chersky mountain ridge. In August - October of 2018 and in June and August of 2021, bird studies of lake basins of Ui, Momontay, Malyk, Darpir and Urultun lakes, situated at altitudes of 818-1234 meters above the sea level, were performed. 81 bird species were registered, of which 69 were recorded during breeding season, including 56 species referred to breeding and 13 , to summering species. In comparison to the bird fauna of neighboring mountain areas, the avifauna of the studied lake systems is characterized by low species diversity, low percentage of widely-distributed species, and high percentage of boreal-hypoartcic and hypoarctic types of zonallandscape distribution with clearly dominating species of the Siberian origin. Species content of the studied area is similar to that of the subalpine belt of Yakutia's northern mountains in the presence of Long-toed Stint, Red-throated Pipit and Pallas' Reed Bunting as well as, contrary to the subalpine belt of the Kolyma Highland, in the absence such species as Pine Grosbeak, Siberian Rubythroat, Pallas' Leaf Warbler, and Arctic Warbler on these elevations. On the other hand, the presence of such species as Ringed Plover and Dusky Warbler and the absence of Bluethroat is similar to the bird fauna of the Kolyma Highland subalpine belt. High abundance of both Beringian and Green-headed Yellow Wagtails sharing their habitats appeared to be a unique feature of the studied area. Confirmed breeding of Fieldfare on the elevations over $1000 \mathrm{~m}$ above the sea level significantly increases the knowledge on the distribution and ecology of this species.
\end{abstract}

Keywords: avifauna, bird distribution, Chersky mountain ridge, lake basins, subalpine belt.

\section{REFERENCES}

Chernov, Yu. I., 1975. Natural Zonality and Terrestrial Animal Wildlife. Moscow, Mysl [In Russian].

Chernov, Yu. I., 1978. Structure of the Subarctic Animal Population. Moscow, Nauka [In Russian].

Dorogoy, I. V., 2018. Second Record of Fieldfare Turdus pilaris Breeding in the North of the Sea of Okhotsk Coast, Russian Journal of Ornithology. 27 (1648), 36913693 [In Russian].

Kishchinsky, A. A., 1968. Birds of the Kolyma Highland. Moscow, Nauka [In Russian].
Kishchinsky, A. A., 1988. Avifauna of Northeast Asia: History and Modern State. Moscow, Nauka [In Russian].

Koblik, E. A., Arkhipov, V. Yu., 2014. Avifauna of the States of Northern Eurasia (Former USSR). Checklists. Zoologicheskie Issledovania No. 14. Moscow, KMK Scientific Press Ltd. [In Russian].

Kondratyev, A. V., 2014. First Breeding Record of Fieldfare Turdus pilaris in Magadan Oblast, Russian Journal of Ornithology. 23 (1045), 2785-2787 [In Russian]. 
Krechmar, A. V., 2014. Ecology and Monitoring of Birds in the Northern Okhotsk Plain Forest Tundra Exemplified by the Kava River Basin Landscapes. Vladivostok, Dalnauka [In Russian].

Krechmar, A. V., Andreev, A. V., Kondratyev, A. Ya., 1978. Bird Ecology and Distribution in the North-East of the USSR. Moscow, Nauka [In Russian].

Lobkov, Ye. G., 2015. State of the Fieldfare Turdus pilaris in the Russian Far East: Progressive Breeding Range Shift, Russian Journal of Ornithology. 24 (1114), 789 791 [In Russian].

Ravkin, Yu. S., 1967. To the Methodology of Bird Counts in the Forest Landscapes, Nature of Tic Encephalitis in Altai. Ed. Maksimov A. A. Novosibirsk, Nauka. 66-75 [In Russian].

Romanov, A. A., 2013. Bird Fauna in the Asian Subarctic Mountains : Regularities in Formation and Dynamics. Moscow, BirdsRussia [In Russian].

Romanov, A. A., Melikhova, E. V., Miklin, N. A., Yakovlev, V. O., 2019. Analysis of the Bird Fauna and Population in the Southern Spurs of the Kolyma High- land, Zoologicheskii Zhurnal. 98 (8), 915-927 [In Russian].

Sinelnikova, N. V., 2018. Fieldfare Turdus pilaris: New Breeding Species in the Northwest of Magadan Oblast, Russian Journal of Ornithology. 27 (1594), 17051707 [In Russian].

Sleptsov, Yu. A., 2018. Breeding of Fieldfare Turdus pilaris in the Upper Kolyma, Russian Journal of Ornithology. 27 (1700), 5800-5802 [In Russian].

Schtegman, B. K., 1938. Basics of the Palearctic Ornithogeographical Division, Fauna of the USSR. Birds, Vol. 1. Iss. 2. Ed. Zernov S. A. Moscow - Leningrad, AS USSR [In Russian].

Vaskovsky, A. P., 1951. Notes on the Findings of Certain Bird Species in the Upper Parts of the Kolyma and Indigirka Rivers, Bulletin of Moscow Society of Naturalists, Biological Series. 56 (1), 22-25 [In Russian].

Vorobyov, K. A., 1959. Ornithological Studies in the Chersky Mountain Ridge, Ornithologia. 2, 115-121 [In Russian].

Vorobyov, K. A., 1963. Birds of Yakutia. Moscow, AS USSR [In Russian]. 